\title{
News and Information
}

\section{Conference Reports}

\section{Transition from Planned to Market Economies Ten Years On at Freie Universität Berlin 18-20 November 1999}

Ten years after the Berlin Wall was brought down, this conference reviewed the transition process in Eastern Europe at Berlin Free University. on this occasion Macmillan Press launched a new book series 'Studies in Economic Transition', which has been established in response to a growing demand for a greater understanding of the transformation of economic systems. A number of its authors took part in the conference, which was organised by the general editors of the series, Jens Hölscher and Horst Tomann and sponsored by the FritzThyssen-Foundation. The event opened with a panel discussion addressing the general issues of ten years of economic transition, which was open to the public and found and interested audience including the students of the economics faculty of the Freie Universität Berlin. The panel discussion was chaired by Heik Afheldt, editor of the capital's newspaper 'Der Tagesspiegel', which reported on the conference subsequently. Speakers on the panel were academic representatives of the respective transition countries, which were delegates of the conference about which we report below.

The main part of the conference on country reports covering selected transition economies started with Poland. Michal Federowicz suggested that Poland was "a positive example of shock therapy" in which the state sector was forced into restructuring. However, the therapy was sufficiently gradual to allow time for a well-founded privatization which in particular fostered the emergence of small and medium enterprises. The process benefited from widespread popular support for transition, a moderation of so-called 'nomenclatura privatization' and the reformers' "clear vision of a desired economic system". But the country's technological gap with Western competitors and the maintenance in operation of inefficient firms raise difficulties for the future. Now it appears that the new centre-right government is "not interested in the completion of institutional change".

The discussants of Federowicz's assessment of Poland's transition process, chaired by Hans-Jürgen Wagener, were Cathryn Ross and Julie Pellegrin. Ross based her comments on two topics not covered by Federowicz, namely the prevalence of state aid and the problems she attached to the state of development of Poland's infrastructure-industry. With respect to state aid in Poland, she stressed possible adverse effects on economic efficiency and the problem of adverse selection. Additionally, she expressed her critical view on the form of state aid in Poland, as tax advantages granted to enterprises result in revenue 
forgone and non-collected social security contributions. State aid therefore is hidden in official statistics which will have adverse repercussions on negotiations with the EU. As an example for insufficient infrastructure in Poland, Ross named the telecommunications industry. Here, the national company had been partially privatised, but lacks a foreign, strategic investor. Massive regulation in this sector so far prevented the crucially needed boost in investment. Pellegrin focussed on determinants of competitive capabilities in Poland. On the micro-level, two sets of factors needed further addressing: first, corporate governance and the mechanisms of financing small and medium enterprises and second the role of foreign direct investment and the incorporation of Poland's firms into Western corporate structures played in integrating Poland's firms into foreign production networks to speed up technology and knowledge transfers.

In the open discussion, Adalbert Winkler raised concern with the empirical evaluation of the problems of Poland's development on a micro-level. He felt that the sample was biased and therefore presents a distorted picture. When incorporating the newly emerged small and medium enterprises into the sample, the evaluation might turn out to be far more favourable. Hubert Gabrisch enquired whether the main reason for the fact that data showed little improvement in competitiveness indicators lies with a lack of demand, which Federowicz dismissed stating that Poland was very much a demand driven economy.

Following Poland, the conference shifted to Ukraine, chaired by Hubert Gabrisch. Hans van Zon presented his pessimistic assessment in as much as the recent re-election of President Kuchma would perpetuate the "disastrous state" of the economy and society. He saw path dependency in Ukraine as having engendered a transition economy vitiated by "parasitic mechanisms" formed from Soviet institutions, a "(post)Soviet socio-psychological syndrome persisted as a comprehensive mechanism. The role of a quasi feudal state was overwhelming in production and distribution, its policy was unpredictable, the rule of law was absent and corruption was rampant. In sociological terms, Ukraine was a "Third World patrimonialist".

Winkler, the discussant for this session on Ukraine, focussed on the "antagonism between a strong state and too strong interference between the market and the state". The state should remain an external factor for companies, managers should not be directly involved in shaping the state or its policy. Prompted by this, a discussion on the role of the state in transition emerged: Wagener called for a departure from the Washington Consensus to engender a new research programme. With view on the case of Ukraine, he demanded the introduction and enforcement of the rule of law as basic principle for post Soviet transition economies. 
The third country report on the Czech Republic, chaired by Gennady Bogomazov, was presented to the audience by František Turnovec. He held that "the transition economy was never in such a good shape as it looked from overoptimistic evaluations in the early 1990s (strongly supported by government propaganda), nor in such a bad situation as some external auditors imply at the end of the 1990". The inheritance in 1989 of competent management in a comprehensive state sector, low inflation, a trade surplus and a balanced budget had not been utilised after the political change, due principally to a serious mismanaged privatisation programme and to indirect subsidies by state banks as loans which soon proved non-performing. Economic recession led to political crisis and the displacement of the "right-centre" Premier, Vaclav Klaus, and eventually to a split in his Civic Democratic Party. The completion of privatisation, notably of banks, and debt-for-equity swaps for bad loans by the administration of the Social Democratic Party now allowed hope of a stable market economy.

Hella Engerer, Turnovec's discussant, pointed out that the prime reason for the disappointing performance of the Czech Republic from 1997 onward was the problem of non-transparent ownership structures. The Czech Republic depleted its initial advantages when the privatisation process did not take account of the problem of corporate governance. This gave rise to a structure of crossownership that lacked a clear division of responsibilities. Further comprehensive institutional change, including further reforms of the solvency laws as well as soft factors like the reliability of outcomes of reforms, were needed to put the Czech Republic back on a sustainable path of economic development. With respect to the "Synthetic Measure" - indicator for the evaluation of transition reforms suggested by Turnovec, she suggested that further fine-tuning was needed, as the indicator would exaggerate a negative assessment if profound restructuring was ventured but typically produced unemployment. Gabrisch added that next to targeting privatisation on the scope of ownership changes, the state and the partners in the wage-bargaining process have the responsibility to complement privatisation with incomes policies. The scope and success of internal restructuring of companies crucially depends on the development of real wages; since 1994, the development of labour costs and the exchange rate in the Czech Republic did not support internal restructuring. Winkler raised concern with the failure of Czech's mass-privatisation policies to enforce a hard budget constraint on companies, giving rise to the phenomenon of 'bad loans' and Ross called for research on the Czech Republic that extends from its preliminary focus of privatisation to the evaluation of competitiveness of Czech companies.

Slovakia, too, in a paper presented by Jarko Fidrmuc and chaired by Zbigniew Polanski, had suffered from economic policies pursued while it was part of Czechoslovakia and from a recession which affected the Slovak part more severely than the Czech part. After the division of the state in 1993 and the 
abandonment within six weeks of the Czech-Slovak Monetary Union, it experienced high budgetary and external deficits and heavy unemployment, which latter was a factor in the return of an authoritarian government in 1994 and "several violations of the constitution, basic human rights and the rights of minorities". Following the victory of the democratic coalition in 1998 elections, economic liberalisation has begun, but "corruption and cronyism are still widespread". Fidrmuc devoted much of his presentation to the potential benefit which accession to the EU could bring Slovakia.

In discussing Fidrmuc's presentation, Anja Hochberg pointed to the special relationship between the Czech Republic and the Slovakia when considering their respective dates of membership with the EU. Her comments focussed on the development of productivity in Slovakia, as within the EU, the fixity of exchange rates would not grant gradual nominal devaluation to compensate for the existing, though narrowing, productivity-gap. Laszlo Csaba, acknowledging political change in Slovakia, questioned the parallel improvement of economic reforms and development.

The paper on Russia by Vladislav Semenkov contended that the financial crisis of 1997 demonstrated the failure of transition in Russia. Quite in contrast to the evaluation of the Ukraine by van Zon, Semenkov held that this stemmed from a "reckless neo-bolshevik destruction of the Soviet political and economic institutions during perestroika and following the shock therapy of Gaidar's liberalisation [leaving] economic agents in an institutional vacuum", i.e. the failure to establish property rights and mutual trust.

Michael Kaser, his discussant, took issue with his claim that more of the Soviet institutions should have been retained, because it was they which had generated the present informal economy for both households and enterprises and the prevalence of corruption in the state sector. Price liberalisation had initiated high inflation principally because of unexpected supply-side rigidities and privatisation had failed to generate sound corporate governance or attracted major foreign investors because of flawed legislation and of persons who influenced government measures for their own economic and political advantage. The gaining of the IMF's goal of low inflation had been achieved at the cost of excessive short-term government debt, the rolling-over of which depended upon foreigners' confidence and required even higher interest rates to be paid. That fragile confidence was broken by a set of coincidental factors in the first half of 1997, but was now being restored as a sharp real depreciation of the rouble endowed industry with competitive power against imports and for exports to other former Soviet states. In the open discussion, Federowicz held that Poland and Russia could be taken to be opposite cases in as much as Poland took advantage of the historical opportunity for sound reforms whilst Russia's failure lied in the lack of constructive reforms. 
Laszlo Csaba, chaired by Jens Hölscher, opened his paper on Hungary with the statement that "Hungary does not fit into the doomsday-visions of transition" and has shown that the recent moderate GDP growth is sustainable. He made the provison that the small open economy had been hit by external shocks such as the collapse of CMEA or the Asian crisis and that the centre-right government of 1998 had "consciously relegated the Ministry of Finance to an accountancy department", with neither the Ministry of Economy nor the Premier's Office formulating policy. The international capital market is already more important in shaping allocation decisions than in a number of EU states. Before Hungary gains EU membership it needs further disinflation and fiscal reforms that transform the public sector into a net saver.

In his comment, Johannes Stephan focussed on two prominent areas in Csaba's paper on Hungary, namely first the quality or "sustainability" of GDP growth in Hungary and second the optimistic view expressed by Csaba on a "selfpropelling convergence process via integration into the EU'. In complementing Csaba's assessment of the Hungarian growth trajectory, Stephan presented some results of an own 'growth accounting' exercise which supported Csaba's view that Hungary's growth process, whilst remaining quantitatively less impressive, exhibits a higher indicator for 'qualitative' growth than other post-socialist economies and in particular Poland. In respect to the expectable result from EU integration, Stephan held that concepts that expect EU membership to automatically trigger convergence were unfounded when the set of assumptions of integration and foreign trade theories were altered to match the particular conditions in transition economies as 'unequal partners'. Research should therefore focus on the determinants of the productivity gap and the conditions for its closure.

The conference closed with a general discussion on comparative issues of economic transition. There was a widespread agreement among the participants that transformation is more than privatisation and liberalisation, because institution building is at the core of the process. Therefore the academic profession should move away from the 'Washington Consensus'. What exactly should be done was however under dispute.

Johannes Stephan, Halle Institute for Economic Research (IWH), Jens Hölscher, University of Brighton. 


\section{The First International Conference on Management of Technological Change, 22-24 October 1999, Technical University of Iasi "Gh. Asachi", Iasi, Romania}

The First International Conference on Management of Technological Change aimed at bringing together specialists from academic, business and government institutions to discuss new developments and results in the field of management of technological changes with a special emphasis on the needs of transition economies of Central and Eastern Europe (CEE). The Conference was strongly oriented towards the way of managing and implementing change, in general, and particularly for technological transfer within the CEE companies. There were eight topics of sessions where 67 papers were presented. The Conference was attended by academics, practitioners and decision makers from Bulgaria, Canada, Denmark, Hungary, Greece, The Netherlands, Portugal, Romania, Russia, Slovenia, United Kingdom, United States and Yugoslavia.

In the first track "Technological Transfer and Change" nine papers were presented tackling with globalization issues, regional specifics, context characteristics of technology transfer, industry specific issues, etc.

The second track "Managing Strategic Change" contained twelve papers focusing on the experience of large companies, theoretical models, educational institutions strategic approaches to change, strategy and sustaining competitive advantage, etc. "Technological Innovation" as a third track dealt with innovation models and innovation management as well as environmental issues through six papers. "Corporate Culture and Change" track contained five papers focusing mostly on structural changes in companies. The fifth track "Human Resources in the Process of Change" contained eight papers dealing with reengineering issues, HRM development aspects, work efficiency, etc. The sixth track had three papers on TQM and business improvement processes. The seventh track "Process of Change and Organizational Transformation" contained twelve papers. The addressed the issues of organizational change, risk management, knowledge management, country specifics in organizational change, diagnosing approaches, etc. "Tools for Change" had twelve papers dealing mostly with implementation issues in various functional business areas.

The intent of the Conference organizers is to make the event regular.

Marin A Marinov, Visiting Professor of Marketing and International Business Odense University, Denmark

\section{Contact:}

Professor Dr Costache Rusu

tel.: +40 32140055

fax: + 4032213708

email: crusu@misp.tuiasi.ro. 


\section{The Seventh Annual Conference on Marketing Strategies for Central and Eastern Europe Hotel Wimberger Vienna, Austria December 1-3, 1999}

The Conference attracted participation of more than 90 attendees from sixteen countries, namely Austria, Bulgaria, the Czech Republic, Denmark, Estonia, Finland, Germany, Italy, Lithuania, the Netherlands, Poland, Romania, Slovakia, Slovenia, the United Kingdom, and the United States of America. Twenty seven universities and institutions from Europe and North America were presented.

Twenty one papers were delivered at the Conference that dealt with the following issues:

1) 'Direct Investment, Market Entry, and Financial Strategy: Central and Eastern European Perspective' by George Tesar and Hamid Moini from the University of Wisconsin-Whitewater, USA. The paper is focused on the link and interdependence between foreign direct investment, market entry strategy, and financial strategy used by foreign investors in CEE. The Czech Republic, Hungary, Poland, Slovakia, and Slovenia are dedicated particular attention.

2) 'Market and Entry Strategies and Performance of Austrian and Finnish Companies in Central and Eastern Europe' by Jorma Larimo and Jarmo Nieminen from the University of Vaasa, Finland, and Reiner Springer from the University of Economics and Business in Vienna, Austria. Dealing with the issues of motives for market entry in CEE a comparative analysis is performed of the market and entry strategies versus company performance of Austrian and Finnish firms operating in the region.

3) 'Strategies of Western Companies in Central and Eastern Europe' by Jutta Muschen from the University of Wurzburg, Germany. The paper uses the eclectic paradigm developed by John Dunning to analyze the strategies of Western companies functioning in the CEE context.

4) 'Exploring the Incentives and Challengies of U.S. Firms in the Czech Republic: A Case Study Approach' by Richard DeMartino and Stanley Widrick from the Rochester Institute of Technology, USA. Using several case studies the authors explore the incentives and hardships of U.S. firms in the Czech Republic. Similarities and differences are drawn upon.

5) 'Foreign Direct Investment as a Driver of Restructuring the Transitional Economy: Internal and Micro-External Change' by Sonia Ferencikova from the University of Economics in Bratislava, Slovakia. Focusing on the changes in the Slovakian economy caused by FDI the author analyzes the foreign investor inflows in the country as a driver for economic restructuring of Slovakia in its transition towards market orientation.

6) 'The Role of Social Relations in Foreign Direct Investment's in Russia' by Inkeri Hirvensalo, Riitta Kosonen, and Asta Salmi from Helsinki School of Economics and Business Administration, Finland. Analyzing the cultural 
differences between Russia and foreign investor's national characteristics the authors suggest approaches for the foreign investor towards the Russian business environment.

7) Multinational Corporations Internationalization in Central and Eastern Europe: The Experience of Interbrew' by Marin A. Marinov from Odense University, Denmark, and Svetla T. Marinova from the University of Groningen, The Netherlands. Through a detailed case study analysis the paper presents the strategic approaches of the Belgian brewing company Interbrew in CEE. General analysis is conducted for the region as whole, and with a particular reference to the investor's experience in Hungary and Bulgaria.

8) 'Market Research in International Environment' by Karen File from the University of Connecticut, USA, Regina Virvilaite and Laimona Sliburyte from the University of Technology in Kaunas, Lithuania. The approaches of Western companies towards conducting market research in CEE are analyzed with a special reference to the Lithuanian environment.

9) 'Attracting International Investment to Estonia' by Mait Miljan, Mart Sorg and Jaan Omblus from the University of Tartu, Estonia. The paper deals with the characteristics of the process of attracting FDI in Estonia.

10) 'Interpretation of the Role of Marketing in Polish Small and MediumSized Businesses' by Miecyslaw Ciurla and Milleniusz Nowak from the Technical University of Wroclaw, Poland. Trough evaluating the role of SMEs in the Polish economy the role of marketing in them during transition is analyzed.

11) 'Acquisition of Hungary's Tungsram: Cultural Conflict or Harmony 1989-1999' by Paul Marer and Vincent Mabert from Indiana University, USA. Using a case study approach the authors demonstrate the process of developing new culture in the Hungarian company Tungsram after its acquisition by General Electric in 1989.

12) 'Customer Loyalty: A Buzz Word or a Strategic Priority for Slovenian Companies' by Ica Rojsek and Darja Podobnik from the University of Ljubljana, Slovenia. The authors emphasize the importance of customer loyalty for Slovenian companies in the new economic conditions during transition.

13) 'The Re-Emergence of Local Brands in the Transition Economies of Central and Eastern Europe: The Saku Brewery in Estonia' by Steward Arnold from the University of Hull, United Kingdom. The issue of re-emergence of local brands considering the change of life style and rising nationalism in Estonia is demonstrated through the experience of Saku Brewery.

14) 'The Efficiency of Mail Advertising as a Form of Communication with Customers in the North moravian Region' by Lidmila Janeckova and Frantisek Nemec from the Silesian University, The Czech Republic. The customer response from mail advertising is analyzed in a variety of aspects.

15) 'ADRs as Capital Raising Possibility of Enterprise of Eastern Europe' by Roland Leitinger from the University of Economics and Business in Vienna, 
Austria. The role of ADRs in capital raising of enterprises across the CEE region is presented with empirical evidence.

16) 'How to develop Proper Factors of Competitiveness When Being a Small Country Entering the European Union' by Maja Makovec from the University of Ljubljana, Slovenia. The case of Slovenia in developing international competitiveness before entering the EU is dealt with in this paper.

17) 'Multinational Companies on the Bulgarian Emerging Market: Problems and Conditions for Business Activity' by Milena Dishovska from the American University in Bulgaria, Bulgaria. Using several mini cases the author gives some aspects of the characteristics of the business environment in Bulgaria faced by foreign investors.

18) 'Theoretical and Practical Aspects of the Segmentation of the Lithuanian Hotel Market' by Regina Virvilaite and Jurate Banyte from the Kaunas University of Technology, Lithuania. Theoretical and empirical evidence from the segmentation of the hotel market in Lithuania provided.

19) 'Internationalization Strategies of Banks in a Transition Country: Estonian Case' by Mart Sorg, Mait Miljan and Nadezhda Ivanova from the University of Tartu, Estonia. The authors analyze the process of internationalization of the Estonian banking industry in the period 1992-1999.

20) 'A SWOT Analysis of the Romanian Marketing Environment' by Calin Veghes from the Academy of Economic Studies, Romania. Evaluating the opinion of managers of Romanian companies, the author analyzes the marketing environment in the country using SWOT analysis.

21) 'Italian Companies in Albania: An Exploratory Study' by Donata Vianelli and Patrizia De Luca from the University of Trieste, Italy, and Roland Kajca from the University of Tirana, Albania. The paper gives data on the development of the Albanian economy in the period 1992-1999. It provides research evidence from a survey of the Italian companies in Albania functioning there through investment mode of entry.

Marin A. Marinov, Marketing and International Business, Odense University, Denmark

The next Annual Conference on Marketing Strategies for Central and Eastern Europe will take place in Vienna on December 13-15, 2000.

\section{Contact:}

Petr Chadraba, DePaul University, USA email: pchadrab@wppost.depaul.edu
Reiner Springer,

University of Economics and

Business, Vienna, email:

Reiner.Springer@wu-wien.ac.at 


\section{Am 25. und 26. Mai 2000 findet in Osnabrück die Tagung "Umweltberatung und Nachhaltigkeit" der Deutschen Bundesstiftung Umwelt statt.}

Die Tagung wird ausgerichtet vom Lehrstuhl für Soziologie, Prof. Dr. Reinhard Stockmann, Universität des Saarlandes. Die Tagungsunterlagen zur Anmeldung können Sie anfordern bei:

\begin{tabular}{|c|c|}
\hline $\begin{array}{c}\text { Universität des Saarlandes, } \\
\text { Lehrstuhl für Soziologie }\end{array}$ & $\begin{array}{c}\text { email: j.urbahn@rz.uni-sb.de } \\
\text { Julia Urbahn }\end{array}$ \\
Postfach 151150 & Fax: 0681/302-3561 oder 302-3320 \\
66041 Saarbrücken & \\
\hline
\end{tabular}

Der Tagungsbeitrag beträgt 100,- DM (ermäßigter Beitrag für Studierende: 70,- DM). Für Anmeldungen, die nach dem 31. März erfolgen, wird ein erhöhter Beitrag von 130,- DM (ermäßigt: 100,- DM) erhoben.

Aktuellste Informationen zur Tagung finden Sie unter

http://www.uni-sb.de/philfak/fb6/stockmann/umwelt

\section{Russisch-Deutsches Ausbildungsprogramm (RDAP)}

Das russisch-deutsche Ausbildungsprogramm für sozialpsychologische und organisatorische Probleme des Unternehmertums, Business und Managements wurde durch Verträge zwischen der Moskauer Staatlichen Lomonossow-Universität, dem Klaus-Steilmann-Institut für Innovation und Umwelt und der deutschen Universität Witten/Herdecke gegründet.

Die Präsidenten des Rates sind der Rektor der Moskauer Universität, Akademiemitglied W. Sadownitschij und der Initiator der deutschen Seite, Klaus Steilmann.

Im Rahmen des Programms erfolgt die Ausbildung von Studenten, Aspiranten und Hospitanten sowie die Aus- und Weiterbildung von Managern und Unternehmern mittlerer und höherer Ebenen der russischen Wirtschaft.

Im Mittelpunkt der Lehrprogramme stehen Theorie und Praxis des Unternehmertums, Business und der Managemententwicklung sowie Psychologie und Soziologie, Arbeitspsychologie und -soziologie, auf der Basis moderner Methoden und internationaler Vergleiche sowie Fallstudien. Unser Ziel ist es, die Zusammenarbeit mit konkreten Branchen $\mathrm{zu}$ entwickeln. Aus diesem Grund werden wir spezielle Programme für die Aus- und Weiterbildung von Managern und Unternehmern mittlerer und höherer Ebenen der russischen Wirtschaft vorbereiten. Die Struktur des Programms besteht aus: Grundlagenforschung, Lehre und Beratungs- und Kooperationszentrum. Dabei sind die 
Schwerpunkte der Grundlagenforschung die Untersuchung der historischen Entwicklung in Rußland in den Jahren 1900-2010 und dabei der Einfluß solcher Faktoren wie Kultur, Psychologie und Wirtschaftstransformation in Rußland auf das Unternehmertum.

Ausgehend aus unseren Zielen, bieten wir unseren Lehrgangsteilnehmern folgende Lehrinhalte:

$\checkmark$ Grundlagen des Unternehmertums,

$\checkmark$ Entwicklung von Business Plänen,

$\checkmark$ Marketing,

$\checkmark$ Grundlagen des Managements,

$\checkmark$ Finanzierung, Kostenrechnung und Bilanzierung, $\checkmark$ Innovationsmanagement und Kreativitätsentwicklung,

$\checkmark$ Grundlagen der Netzökonomik,

$\checkmark$ Psychologische Grundlagen, Evaluation geeigneter Unternehmerpersönlichkeiten.

Im Ausbildungsprogramm wirken die Fakultät für Psychologie, Fakultät für Mathematik und Kybernetik sowie das Zentrum für soziologische Forschungen an der Moskauer Lomonossow-Universität mit.

Unsere heutigen westlichen Partner sind:

$>$ Klaus Steilmann Institut,

$>$ Universität Witten/Herdecke (Institut für kulturvergleichende Wirtschaftsforschung),

$>$ Ruhr Universität Bochum,

Europauniversität VIADRINA,
$>$ IKT Unternehmen,

$>$ OBI Baumärkte,

$>$ Gesundheitsbranche sowie diverse Dienstleister,

Unternehmen

Nahrungsmittelindustrie.

Die Zusammenarbeit zwischen Rußland und Deutschland bei der Aus- und Weiterbildung von Managern und Unternehmern in Rußland ermöglicht es, effektive gemeinsame Ausbildungsprogramme für Rußland $\mathrm{zu}$ entwickeln und den Lehrgangsteilnehmern notwendige und moderne Kenntnisse der Praxis des Unternehmertums und Managements im gegenwärtigen Rußland zu vermitteln. 
Centre for Research into East European Business and Other Transforming Economies (CREEB)

Sixth Annual Conference on

\section{Corporate and Organizational Restructuring}

20 and 21 June 2000

The conference will explore the process and impact of corporate and organizational restructuring in the countries of Central and Eastern Europe, the Former Soviet Union and other transforming economies. The scope of the conference will combine keynote speakers, paper and poster presentations, discussion, etc.

\section{Topics include:}

$\checkmark$ Old and new organizational forms

$\checkmark$ Organizational cultures

$\checkmark$ Organizational histories

$\checkmark$ Organizational discourses

$\checkmark$ Managers and ways of managing

$\checkmark$ Corporate governance and ethics

$\checkmark$ Personal and organizational networks $\checkmark$ Relationships between companies and localities

$\checkmark$ Organizational partnerships

$\checkmark$ Visions and missions

$\checkmark$ Old and new ways of learning

$\checkmark$ Corporate and organizational restructuring in China

$\checkmark$ New and interesting methodological approaches

\section{Deadlines:}

21 February 2000: Submission of abstracts

15 May 2000: Submission of completed papers (together with disk)

It is intended to publish papers submitted by 15 May 2000 in the conference proceedings.

The conference will be held at Missenden Abbey Management Centre, Buckinghamshire Chilterns University College

Fees, including accommodation, meals and conference proceedings are $£ 175$, research students $£ 115$. The non-residential fee is $£ 140$, research students $£ 90$ ).

\section{Contact:}

CREEB, Buckinghamshire Business School, Chalfont Campus, Gorelands Lane, Chalfont St Giles, Bucks, UK HP8 4AD

Tel: +44 1494603192

Fax: +44 1494874230

email: creeb@bcuc.ac.uk web: http://www.bcuc.ac.uk 


\section{Tacis City Twinning \\ 1999-2001}

\section{Reorganisation der Finanz-ströme in der Stadtverwaltung Jaroslawl}

Das Projekt hat eine Modernisierung der Ver-waltungsstrukturen in der Stadtverwaltung Jaroslawl im Bereich der Haushaltsplanerstellung und -umsetzung zum Ziel.

Fragestellungen: Wie kann eine optimale Verwendung der Finanzen in der Stadtverwaltung er-reicht werden? Diese Fragestellung gliedert sich in zwei Unterpunkte: Wie müssen die Organisationsab-läufe gestaltet sein, um eine optimale Verwendung der Finanzen in der Stadtverwaltung zu erreichen? Welche Qualifikationen benötigen die Mitarbeiter, um die Finanzen optimal zu verwenden?

Laufzeit des Projektes: November 1999 - Januar 2001

Zusammenarbeit: Kernstück des Projektes sind mehrwöchige Arbeitsaufenthalte von Fachleuten und Wissenschaftler/innen in den Städten. Während dieser Arbeitsaufenthalte sollen Strategien und Ver-fahren entwickelt werden, die eine nachhaltige Mo-dernisierung der Stadtverwaltung Jaroslawl auslösen. In Workshops und Seminaren werden diese Strategi-en und Verfahren sowie die zu ihrer Anwendung notwendigen Qualifikationen vermittelt. Akteure außerhalb der Verwaltung werden in die Projektarbeit mit einbezogen.

\section{Erwartete Ergebnisse}

$>$ Die Einführung einer dezentralen Verantwortung für Finanzen in Pilotbereichen.

$>$ Entwicklung eines Konzeptes zur Einführung de-zentraler Budgets in der gesamten Stadtverwal-tung von Jaroslawl.
$>$ Entwicklung eines Curriculums zur Vermittlung der Fähigkeiten, dezentrale Verwaltungs-einheiten zu managen. Der Schwerpunkt dieser Qualifikation soll im Bereich des Finanzmanagements liegen.

> Größere Transparenz der Verwendung öffentlicher Mittel durch die Stadtverwaltung.

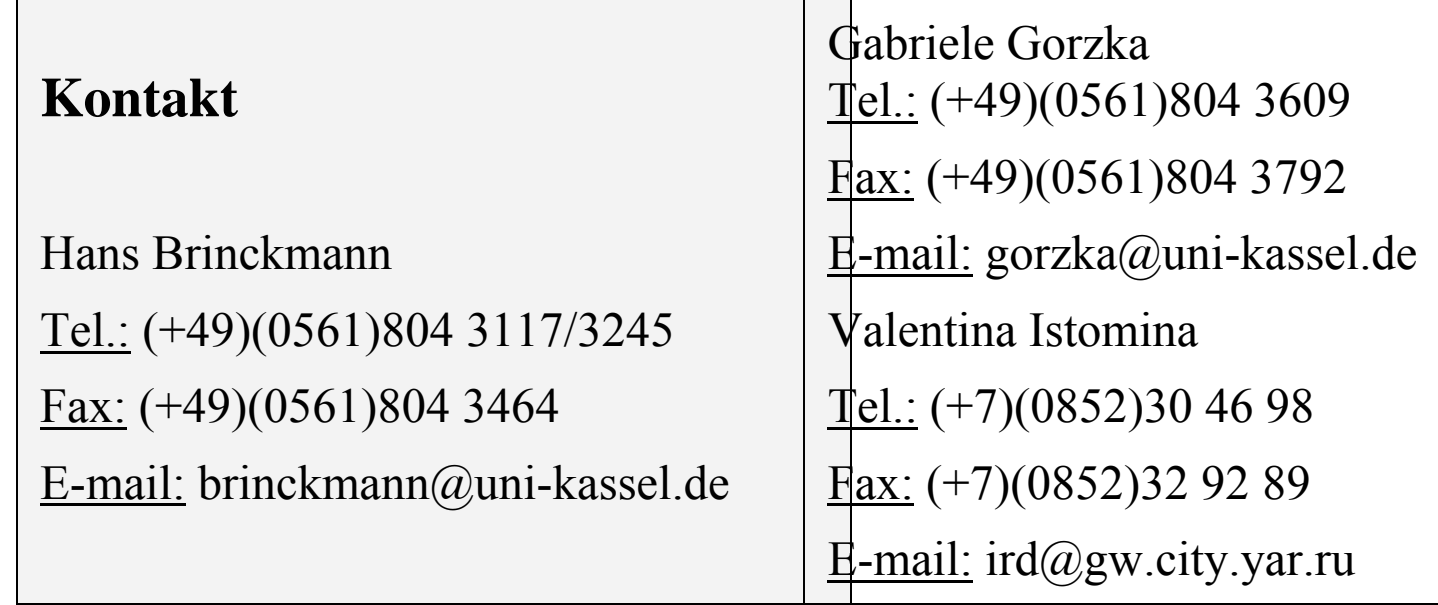




Center for East Europan Studies, Copenhagen Business School
2nd International Conference on
Transition and Enterprise Restructuring in Eastern Europe
HILLERØD, DENMARK,
August 17-19 2000

While Central European countries are on their way into the EU, and into global business networks, many successor states of the Soviet Union are still struggling with the legacy of the 20th century: central plan socialism. The conference aims at bringing together leading researchers focusing on enterprise level transition in Eastern Europe, and the reintegration of East European businesses into the global economy. We expect that the conference and the ongoing communication in the INTER network help us better to understand the challenging processes currently going on in institutions and enterprises in Eastern Europe and the former Soviet Union.

The Center for East European Studies has established a homepage

\section{(http://www.econ.cbs.dk/institutes/cees/workshop/wsindex.html)}

and a mailing list for the network. A database of research instruments and case studies is in preparation. The network is supported by the Danish Social Science Foundation.

\section{Topics}

The conference shall this year focus on the international dimension of transition and enterprise restructuring. Submissions of papers are particularly encouraged on the following themes:

$>$ entry strategies of foreign investors alternative forms of international cooperation internationalization of East European businesses and integration in international business networks knowledge transfer 2. International Management

$>$ cross-cultural management in EastWest organizations post-acquisition management management of organizational and strategic change 3 . Corporate Governance:

$>$ long-term implications of alternative privatization policies. performance implications of different ownership structures and institutional environment

\section{Deadlines}

For abstracts: March 1, 2000.

For ompleted papers(together with disk): July 1, 2000.

Conference fee (including accommodation, meals, and conference proceedings): 3.000 DKK (approximately 420 US\$).

\section{rnntart}

Jesper Grundtvig or

Niels Mygind

Center for East European Studies
Conenhaoen Rucinesc Srhonl

Dalgas Have 15

DK-2000 Frederiksberg

Denmark

Phone: +45 38153030 
Fax: +4538153037

E-mail:jg.cees@cbs.dk 